\title{
Effect of secondary prevention on all-cause mortality in Czech survivors of myocardial infarction: a population-based study
}

\author{
Jan Pitha, Ivana Podrapska*, Philip H. Frost**, Rudolf Poledne, Zdenek Valenta***, Richard J. Havel** \\ Laboratory for Atherosclerosis Research, Institute for Clinical and Experimental Medicine, Prague, *Department of Diabetology, \\ Litomerice District Hospital, Litomerice, Czech Republic, **Cardiovascular Research Institute and Department of Medicine, University \\ of California San Francisco, USA, ***Department of Medical Informatics, Institute of Computer Science AS CR, Prague, Czech Republic
}

Pitha J, Podrapska, Frost PH, et al. Effect of secondary prevention on all-cause mortality in Czech survivors of myocardial infarction: a population-based study. Cor Vasa 2009;51(1):13-18.

Background: In spite of successful introduction of interventional treatment of acute coronary syndromes in Czech Republic, recent surveys show that coronary intervention and drug therapies need to be combined with a lifestyle and risk factor intervention. We assessed the effect of intervention after myocardial infarction targeting multiple risk factors in a high-risk population with limited access to hypolipidemic drugs and revascularization.

Methods: In 1992-1993, we enrolled all men under age $60(n=68)$ and all women under age $65(n=40)$ who survived myocardial infarction and were discharged from a single coronary care unit in an 18-month intervention program targeting dyslipidemia, smoking and highly saturated fats diet. Thirty $\%$ were diabetic and $46 \%$ of the remainder fulfilled ATP III criteria for the metabolic syndrome.

Results: After one year, non-HDL cholesterol fell by $27 \%$, smoking from $47 \%$ to $16 \%$, and diet scores were substantially improved. As compared with a control population of 96 patients discharged from this CCU during the same period in 1990-1991, all-cause mortality in men was significantly reduced over 2.6 years (hazard ratio ranging from 0.083 to 0.18 ) and remained lower over 6.7 years of maximum follow-up. Among women, all-cause mortality was not significantly changed by the intervention.

Conclusion: Multifactor intervention after myocardial infarction in men under age 60 with limited access to revascularization procedures dramatically reduced all-cause mortality for 2.6 years.

Key words: Secondary prevention - Myocardial infarction - Metabolic syndrome - Diabetes mellitus

Pitha J, Podrapska I, Frost PH, et al. Vliv sekundární prevence na celkovou mortalitu Čechů, kteří přežili infarkt myokardu: popuIační studie. Cor Vasa 2009;51(1):13-18.

Úvod: Přes úspěšné zavedení intervenční léčby akutních koronárních syndromů v České republice průzkumy z poslední doby prokázaly, že koronární intervence a farmakologickou léčbu je nutno kombinovat s ovlivněním životosprávy a rizikových faktorů. Hodnotili jsme vliv intervencí po infarktu myokardu, zaměřených na řadu rizikových faktorů u vysoce rizikové populace s omezeným přistupem k hypolipidemikům a revaskularizačním výkonům.

Metody: V letech 1992-1993 jsme do 18měsíčního programu intervence zaměřeného na dyslipidemii, kouření a stravu s vysokým obsahem nasycených tuků zařadili všechny muže ve věku do 60 let $(n=68)$ a všechny ženy mladší 65 let $(n=40)$, kteří přežili infarkt myokardu a byli propuštěni z jediné koronární jednotky. Ve $30 \%$ se jednalo o diabetiky a $46 \%$ zbývajících jedinců splňovalo kritéria ATP III pro metabolický syndrom.

Výsledky: Po jednom roce klesla koncentrace non-HDL-cholesterolu o $27 \%$, podíl kuráků ze $47 \%$ na $16 \%$, a skóre stravy se podstatnou měrou zlepšila. Ve srovnání s kontrolní populací 96 pacientů propuštěných z uvedené koronární jednotky ve stejném časovém intervalu v letech 1990-1991 se celková mortalita u mužů za 2,6 let statisticky významně snižila (poměr rizik se pohyboval v rozmezí od 0,083 do 0,18) a zůstala nižší po 6,7 let, což byla maximální doba sledování. U žen uvedené intervence celkovou mortalitu významně neovlivnily. Závěr: Multifaktoriální intervence po infarktu myokardu u mužů mladších 60 let s omezeným přístupem k revaskularizačním výkonům radikálně snížily celkovou mortalitu po dobu 2,6 let.

Klíčová slova: Sekundární prevence - Infarkt myokardu - Metabolický syndrom - Diabetes mellitus

Address: Jan Pitha, M.D., Ph.D, Laboratory for Atherosclerosis Research, Videnska 1958/9, 14021, Prague, Czech Republic, e-mail: japi@medicon.cz

This study was supported by a grant from the U. S. State Department, Agency for International Development (EUR-0037-G-2026-00), by research grant NR/9093-4/2006 Internal Grant Agency of Czech Ministry of Health and the Institutional Research Plan AV0Z10300504 "Computer Science for the Information Society: Models, Algorithms, Applications". 


\section{Introduction}

In spite of successful introduction of interventional treatment of acute coronary syndromes in the Czech Republic, ${ }^{(1)}$ recent surveys show that coronary intervention and drug therapies need to be more efficiently combined with a lifestyle and risk factor intervention. ${ }^{(2)}$ Secondary prevention of ischemic heart disease, most notably treatment with lipid-lowering drugs, significantly reduces cardiovascular mortality. Most studies, however, have continued to focus on a single risk factor: LDL cholesterol. Recently, two trials have evaluated the efficacy of multifactor intervention. ${ }^{(3,4)}$ In these and other trials, patients have been selected using numerous criteria; generalization of such results is therefore uncertain.

We initiated an intervention program to evaluate the efficacy of multifactor intervention focused on several risk factors for cardiovascular disease (smoking, unhealthy dietary habits and dyslipidemia) after acute myocardial infarction in a Czech population shortly after the Velvet Revolution of 1989. At that time, Czechoslovakia had the second highest cardiovascular mortality in the world ${ }^{(5)}$ and smoking was highly prevalent. ${ }^{(6)} \mathrm{A}$ traditional Czech diet is rich in fatty acids, primarily due to popular pork meat consumption and subsidization of pork meat production. Obesity was highly prevalent among adults, particularly outside major population centers. According to later EUROASPIRE I + II observations in 1995-1996(7) and 1999-2000, ${ }^{(8)} 30-40 \%$ of patients in the Czech Republic were obese. In 1999-2000, waist circumference in $80 \%$ of them exceeded $94 \mathrm{~cm}$ (men) and $88 \mathrm{~cm}$ (women). Furthermore, plasma triglycerides exceeded $2.0 \mathrm{mmol} / \mathrm{L}$ in $29 \%$ of men and women. In the early 1990s, invasive coronary procedures were performed only in several centers in the Czech Republic up to 1995, the population had almost no access to hypolipidemic drugs with the exception of fibrates; however, even those were underused.

Our program provided a unique opportunity to understand the impact of modern medicine when suddenly introduced into a culture conducive to atherosclerotic cardiovascular disease and lacking many of the resources than even then were considered necessary to treat such patients. It was carried out in a predominantly rural district of northern Bohemia in which all patients with myocardial infarction were admitted to the Coronary Care Unit (CCU) of the single hospital that served the entire population. For logistical reasons, we confined our intervention of 18 months to men under age 60 and women under age 65 at admission. We compared all-cause mortality during this period and for a total of 6.7 years with a control population of comparable patients admitted to this CCU two years earlier and, in a separate analysis, with secular changes in all-cause mortality in the general population of the district.

\section{Methods}

Intervention population: The intervention population (IP) included all men below age 60 and women below age
65 admitted to the coronary care unit (CCU) of Litomerice District Hospital with myocardial infarction from October 1, 1992 through December 31, 1993. Myocardial infarction was defined according to World Health Organization criteria (presence at least two from the following - clinical symptoms, ECG changes and biochemical markers). Blood was obtained for analysis of plasma lipids immediately upon admission from all patients whose initial symptoms had occurred within the previous 24 hours. During hospitalization, patients were counseled about appropriate dietary habits and, as needed, to stop smoking.

One month after discharge, patients returned to a special ambulatory clinic for baseline evaluation (medical history and general physical examination). Blood pressure, height, weight, and waist and hip circumferences were obtained using MONICA (Monitoring trends in cardiovascular disease and risk factors) study procedures. ${ }^{(9)}$ Fasting blood was drawn for analysis of serum and lipoprotein-lipids and glucose. Additional criteria used to evaluate risk status were smoking (at least one cigarette per day during the preceding three months), diabetes (at least one of the following: fasting plasma glucose greater than $7.0 \mathrm{mmol} / \mathrm{L}$, taking hypoglycemic medication, and history of diabetes) and hypertension assessed by self-report because of unreliability of blood pressure measurements during acute phase of myocardial infarction or at the follow-up visits, when patients are treated with beta-blockers.

Patients also completed a food-frequency questionnaire, the Eating Pattern Assessment Tool (EPAT). ${ }^{(10)}$ The EPAT provides two scores (in servings per week), one assessing the consumption of foods high in fat and cholesterol (EPAT 1) and another assessing consumption of low-fat foods, including fruit and vegetables (EPAT 2).

Serum, VLDL, LDL and HDL lipids were quantified by established ultracentrifugal and enzymatic procedures at the Institute of Clinical and Experimental Medicine (IKEM) in Prague. The Institute Laboratory participates in the Lipid Standardization Program of the Communicable Disease Center in Atlanta, GA. Because of the high prevalence of hypertriglyceridemia in the Czech population, non-HDL cholesterol was the primary target of lipid-lowering therapy. ${ }^{(11,12)}$

\section{Intervention}

Our principal aims were reduction/elimination of smoking, adoption of more healthful dietary habits, reduction of body weight, and lowering non-HDL cholesterol below $3.0 \mathrm{mmol} / \mathrm{L}$. Patients were counseled intensively and repeatedly about smoking and dietary habits by the clinic physician and dietician. The decision to initiate hypolipidemic drugs was based on non-HDL cholesterol and other lipid concentrations within 24 hours after the myocardial infarction and at baseline. During the next 18 months, clinic visits were scheduled every 1-3 months according to the therapeutic response. The complete baseline examination was repeated after 12 and 18 months.

Control population: A control population (CP) was selected retrospectively to include all patients admitted to 
the CCU of the Litomerice District Hospital with established myocardial infarction from October 1, 1990 through December 31, 1991 who fulfilled the same age criteria as the IP. All available data, including risk factors for cardiovascular disease, were obtained from the discharge documents. Serum cholesterol was measured in the hospital laboratory with the same method and results as in the IKEM Laboratory.

Intervention in the CCU: A total of 42 and 53 thrombolyses were performed in the CCU during 1990/1991 and 1992/1993, respectively. In the IP, 14 men and 4 women underwent thrombolysis. Data about particular patients in the historical group are unknown. No patient in either group underwent a revascularization procedure before hospital discharge.

Data analysis: Follow-up of both groups ended on July 1, 1999. Data on survival status and date and cause of death between 1990 and 1999 were obtained for all patients from the Institute of Health Information and Statistics of the Czech Republic. Mortality data for the general population of the same age range in Litomerice District were obtained from the same source. For deceased patients, if uncertain or conflicting information was found, data were confirmed with local physicians. During April/May 1999, a questionnaire was sent to all living control and intervention patients. Response rate on July 1, 1999 was $85 \%$ in the IP and $78 \%$ in the CP.

Data summaries are presented as absolute or relative frequencies for categorical variables and as ranges and means with standard deviations for continuous ones. Fisher exact test was used for comparison of proportions. The differences in selected continuous risk factors between the baseline and 12 months of follow-up were analyzed using the paired $t$-test. The level of significance was set at $p<0.05$.

Kaplan-Meier survival analysis was used to evaluate all-cause mortality. The log-rank test was used to evaluate differences in overall survival between the intervention and control groups. In men, the intervention effect adjusted for age and diabetes mellitus status did not appear to remain constant over time. Gray's time-varying coefficients model was therefore employed to evaluate covariate effects on survival. ${ }^{(13,14)}$ In women, in whom the effects of age, diabetes mellitus status and intervention did not vary significantly over time, adjusted intervention effect on survival was assessed using the Cox proportional hazards model ${ }^{(15)}$ and, for comparison with men, Gray's model as well.

\section{Results}

Group assignments: In 1992/1993, 264 patients were admitted to the CCU, of whom 113 met our age criteria. Four patients died in the CCU and one declined participation. The remaining 108 (68 men and 40 women) comprised the IP. At the 18 -month visit, all men and all but two women continued to participate. The CP was drawn from 101 of the 210 patients admitted to the CCU during 1990/1991 who met our age criteria. Five died in the CCU and the remaining 96 (65 men and 31 women) comprised the CP.
Baseline characteristics and treatment: General characteristics and risk factors in the two populations were well matched (Table 1). Baseline data in the IP (Table 2) show a high prevalence of established risk factors. The prevalence of the metabolic syndrome, together with diabetes mellitus (DM), was $57.4 \%$ in men and $70 \%$ in women. At baseline, $37 \%$ of men and $46 \%$ of women initiated treatment with hypolipidemic drugs and, at 12 months, $93 \%$ of men and $87 \%$ of women were on this therapy, mainly using simvastatin (mean dose $14.3 \mathrm{mg} /$ day). At this time, fewer than $5 \%$ of patients with ischemic heart disease in the Czech Republic were being treated with hypolipidemic drugs and statins were virtually unused. ${ }^{(16)}$ Beta-sympatholytics were used by $55 \%$ and aspirin by $90 \%$ of patients.

Clinical outcomes: At 12 months, there was a major reduction in prevalence of smoking and substantial improvement in atherogenic lipoprotein-cholesterol and EPAT scores (Table 3). These changes were highly significant. The maximum follow-up from hospital discharge for the IP was 2,462 days. The same cut-off point was used for the control population. Median follow-up was 2,462 days in the $\mathrm{CP}$ and 2,231 days in the IP. During follow-up, 9 men (13.2\%) and 7 women (17.5\%) died in the IP; in the CP, 16 men (24.6\%) and 3 women (9.6\%) died. Acute myocardial infarction was the leading cause of death: 4 men and 4 women in the IP, and 10 men and 1 woman in the CP. All cardiovascular diseases caused the death of 7 IP men and 6 women and $14 \mathrm{CP}$ men and 3 women. All other deaths were from malignancies.

Figure 1 shows all-cause mortality in the two populations by gender expressed as Kaplan-Meier plots. Assuming equal mortality rates in the two groups of men, the number of deaths expected for the IP was higher than that observed (13.5 vs. 9) while, in the CP, the number of deaths expected was lower than that observed (11.5 vs. 16). The log-rank test indicated a significant difference in cardiovascular mortality for the two groups $(p=0.048)$. Similar results were found for all-cause mortality. In this comparison, the difference for the two groups of men was only marginally statistically significant $(p=0.07)$. All-cause mortality was higher than expected in

Table 1 Characteristics of the intervention and control populations upon admission to the Coronary Care Unit (mean [SD] or \%)

\begin{tabular}{llll}
\hline & $\begin{array}{l}\text { Intervention } \\
\text { population }\end{array}$ & $\begin{array}{l}\text { Control } \\
\text { population }\end{array}$ & $p$-value \\
\hline Men/women $(\mathrm{n})$ & $68 / 40$ & $65 / 31$ & - \\
\hline Age (years) & $53.2(6.7)$ & $51.6(7.8)$ & 0.115 \\
\hline Body weight $(\mathrm{kg})$ & $86.1(14.8)$ & $81.7(13.5)$ & 0.029 \\
\hline More than 1 MI (\%) & 23.4 & 24.0 & 1.000 \\
\hline Diabetes mellitus (\%) & 29.6 & 37.4 & 0.291 \\
\hline Hypertension (\%) & 38.0 & 29.2 & 0.236 \\
\hline Smoking (\%) & 47.2 & 55.2 & 0.265 \\
\hline Total cholesterol (mmol/L) & $6.75(1.32)$ & $6.39(1.45)$ & 0.073 \\
\hline Ml - myocardial infarction & & &
\end{tabular}


Table 2 Characteristics of the intervention population at baseline

\begin{tabular}{|c|c|c|c|}
\hline & $\begin{array}{l}\mathbf{n} \\
\text { (Men/Women) }\end{array}$ & $\begin{array}{l}\text { Men } \\
\text { Mean (SD, Range) or \% }\end{array}$ & $\begin{array}{l}\text { Women } \\
\text { Mean (SD, Range) or \% }\end{array}$ \\
\hline Age (years) & $68 / 40$ & $52.0(6.0,29.9-61.1)$ & $55.3(7.5,38.5-64.9)$ \\
\hline Diabetes mellitus (\%) & $68 / 40$ & 32.4 & 25.0 \\
\hline Smoking (\%) & $68 / 40$ & 51.5 & 40.0 \\
\hline Hypertension (\%) & $68 / 40$ & 35.2 & 42.5 \\
\hline Body Mass Index (kg/m²) & $68 / 40$ & $29.7(4.4,19.8-41.3)$ & $31.8(5.6,21.3-44.7)$ \\
\hline Waist circumference $(\mathrm{cm})$ & $67 / 37$ & $103.0(11.2,74.0-131.0)$ & $100.5(12.8,78.0-129.0)$ \\
\hline Total cholesterol (mmol/L) & $67 / 39$ & $6.54(1.20,3.31-9.49)$ & $7.10(1.45,5.21-12.80)$ \\
\hline Non-HDL cholesterol (mmol/L) & $67 / 38$ & $5.25(1.23,2.27-8.47)$ & $5.57(1.46,3.67-11.48)$ \\
\hline LDL cholesterol (mmol/L) & $57 / 34$ & $4.05(1.08,2.04-7.54)$ & $4.36(0.89,2.78-6.16)$ \\
\hline HDL cholesterol (mmol/L) & $68 / 38$ & $1.28(0.39,0.71-3.03)$ & $1.52(0.41,0.96-2.76)$ \\
\hline Triglycerides (mmol/L) & $66 / 39$ & $2.87(1.73,1.28-11.70)$ & $3.01(2.63,0.93-13.52)$ \\
\hline Glucose (mmol/L) & $67 / 40$ & $6.39(2.20,3.90-14.60)$ & $6.43(2.19,3.90-13.20)$ \\
\hline
\end{tabular}

IP women (7 vs. 5.1) and lower in CP women (3 vs. 4.9), but the difference was not significant $(p=0.22)$.

The Kaplan-Meier analysis revealed an overall effect of DM status on survival in the IP and CP combined. After 6.7 years, $28.8 \%$ of the diabetics but only $12.0 \%$ of the non-diabetics had died. The log-rank test $\chi^{2}$ statistics of 8.7 on 1 degree of freedom yielded a $p$-value of 0.0032 . This finding was largely driven by the data on male population ( $p=0.0039$ ), whereas the difference observed for the comparatively smaller number of women remained non-significant $(p=0.482)$.

The age- and DM-adjusted effect of intervention in the male populations varied significantly over time. Gray's time-varying coefficients model (13) using 12 knots and 4 degrees of freedom for penalized splines was therefore adopted for male populations. Figure 2 shows that the upper 95\% confidence limit of the log-hazard ratio for the intervention effect remains below zero for approximately 1,000 days of follow-up (exact estimate is 941 days). The intervention effect thus remained significant for about 2.6 years, with hazard ratio (HR) estimate varying from 0.083 to 0.180 . Thereafter, the log-hazard ratio estimate remained close to zero, suggesting similar hazards in the IP and CP.

In women, the effect of age, diabetes mellitus and intervention status, respectively, on patient's survival did not reach the level of statistical significance. Furthermore, these effects appeared to have remained relatively constant over time, warranting the use of the Cox PH model, which indicated that the age-adjusted intervention effect was not statistically significant. The analysis for the two sexes combined yielded the same result as for men: the intervention effect remained significant for about 2.6 years, but not thereafter (data not shown).

Among responders to the 1999 questionnaire, the reported incidence of new myocardial infarction (IP 43\%, CP 48\%) and stroke (IP 7.6\%, CP 8.0\%) was similar. Reported angina pectoris was also similar (IP 28\%, CP 31\%), but revascularization procedures were fewer in the IP $(20 \%$ vs. $28 \%$ ). Sixty-one percent of the IP, but only $17 \%$ of the CP were taking statins. Fibrates were used by $20 \%$ and $17 \%$, respectively. Seventy four percent of the IP and $80 \%$ of the CP reportedly used aspirin; $51 \%$ and $41 \%$ used beta-blockers. Angiotensin inhibitors were not included in this analysis because of their later introduction.

\section{Comparison with the general population}

Since our intervention and control groups are population-based, we compared secular changes in all-cause mortality in the general population of Litomerice District with those observed in our IP and CP (Table 4). For IP men, the observed deaths were only slightly higher than those expected for the general population whereas observed deaths in CP men were increased three-fold. Among the smaller number of IP and

Table 3 Change in risk factors in the intervention population after 12 months (Mean change and 95\% confidence intervals)

\begin{tabular}{|c|c|c|c|c|}
\hline & Men $(n=68)$ & $p$-value & Women $(n=39)$ & $p$-value \\
\hline Smoking (\%) & $-32.4 \%$ & $<0.001$ & $-29.5 \%$ & 0.007 \\
\hline Body mass index $\left(\mathrm{kg} / \mathrm{m}^{2}\right)$ & $-0.42(-0.88 ;+0.04)$ & 0.074 & $-0.38(-0.95 ;+0.18)$ & 0.175 \\
\hline Non-HDL cholesterol (mmol/L) & $-1.35(-1.66 ;-1.07)$ & $<0.001$ & $-1.70(-2.14 ;-1.25)$ & $<0.001$ \\
\hline EPAT $1 *$ & $-4.69(-6.66 ;-2.72)$ & $<0.001$ & $-4.45(-5.92 ;-2.97)$ & $<0.001$ \\
\hline EPAT $2^{*}$ & $+2.24(+1.39 ;+3.09)$ & $<0.001$ & $+1.84(0.74 ; 2.94)$ & 0.002 \\
\hline
\end{tabular}

*EPAT - Eating Pattern Assessment Tool 


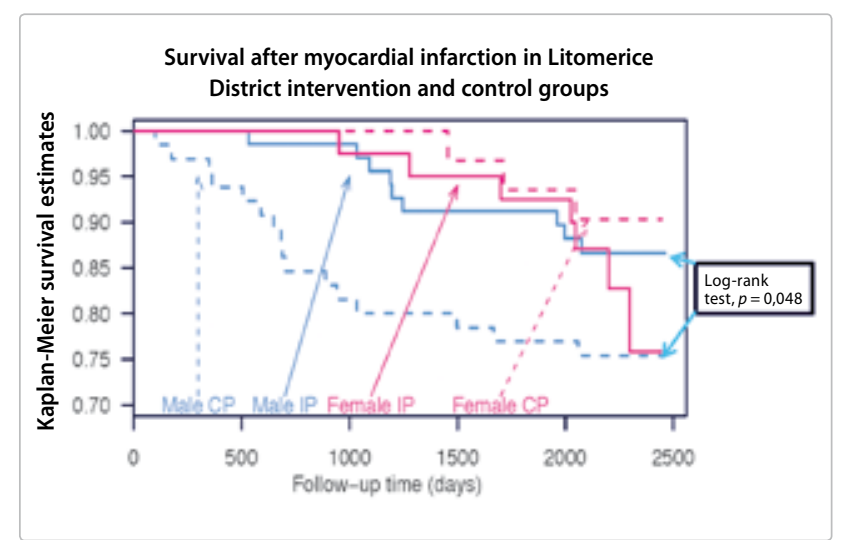

Figure 1 Kaplan-Meier survival estimates for male and female patients: 6.7 year follow-up

$\mathrm{CP}$ - control population, IP - intervention population

$\mathrm{CP}$ women, the observed deaths were higher than expected in the general population, but the difference was greater in the IP. This difference was not statistically significant. Approximately one-half of the deaths in IP women occurred during the last 1.7 years of follow-up.

\section{Discussion}

This prospective, population-based study has shown that early intervention targeting multiple cardiovascular risk factors reduced all-cause mortality in young Czech myocardial infarction survivors during the 1990's. These patients were characterized by a remarkably high prevalence of smoking (47\%), type 2 diabetes mellitus (30\%), obesity (51\%), and hypertriglyceridemia (66\%). The prevalence of these risk factors mirrors that of the Czech population as a whole. ${ }^{(7,8,17)}$ We observed a striking reduction in all-cause (mainly cardiovascular) mortality among men during the planned intervention period of 18 months, continuing for the first 2-3 years after hospital discharge, with no difference from the control population thereafter. Our observation (Table 4) that all-cause mortality among IP men, of whom almost one-third were diabetic, was only slightly higher than that expected for all Litomerice District men of the same age during the entire 81 months of follow-up is

Table 4 Comparison of observed deaths in intervention and control populations (based on 6.7 years of follow-up) with those expected in the general population of Litomerice District

\begin{tabular}{lllll}
\hline Population & \multicolumn{2}{l}{ Intervention population } & \multicolumn{2}{l}{ Control population } \\
\hline Gender & Male & Female & Male & Female \\
\hline Observed deaths & 9 & 7 & 16 & 3 \\
\hline Expected deaths & 6.37 & 2.61 & 5.21 & 2.39 \\
\hline
\end{tabular}

Mortality rates in the general population were calculated as a weighted average of the rates available for the respective follow-up periods for each of four age groups ( $35-44,45-54,55-64$ and $65-74$ years) pertinent to the intervention and control populations, respectively.

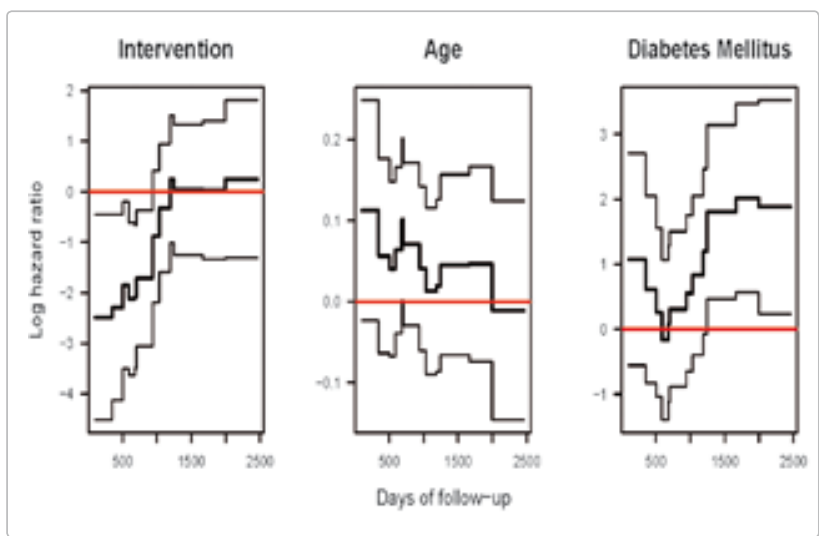

Figure 2 Time-varying log-hazard ratio estimates of fatal event with $95 \%$ confidence limits based on Gray's model, male subjects (intervention and control group together)

The thick line represents the effect of intervention and its modification by age and diabetes mellitus

consistent with an important intervention effect and, to our knowledge, unique.

Because our intervention was multifactorial, we cannot attribute our results to reduction of any given risk factor. However, the most impressive change in the intervention group during the planned intervention period was the observed reduction in smoking from 47 to $16 \%$. Smoking cessation is known to reduce coronary heart disease. ${ }^{(18)}$ Insulin insensitivity among smokers may be particularly adverse in patients with the metabolic syndrome. ${ }^{(19)}$

At the end of the planned intervention period, $90 \%$ of our patients were taking hypolipidemic drugs (two-thirds statins) and their diet was substantially improved. Until 1995, our control population had almost no access to hypolipidemic drugs. By 1999, reported use of statins was $60 \%$ in the IP and 15\% in the CP and that of fibrates was $20 \%$ and $17 \%$, respectively. An additional explanation for the reduced mortality in the CP from 1993-1999 is the secular improvement in the Czech diet after the political and economic changes after 1989, including dramatically increased availability of fruits and vegetables and reduced consumption of fatty pork meat. ${ }^{(20)}$

We observed no significant difference between all-cause mortality in IP and CP women at any time and mortality among CP women was surprisingly low. The main reason is the low number of involved women participants. A more hypothetical reason, based on data published elsewhere, is delayed admission of women to coronary care units, ${ }^{(21,22)}$ leading to elimination of women at highest risk of death from hospital discharge cohorts. For our CP women, this possibility is supported by the fact that $21 \%$ of men but only $10 \%$ of women in the IP received thrombolytic therapy, which suggests that most women were admitted more than 12 hours after the onset of symptoms.

A limitation of our study is the use of a historical control population, which made it impossible to quantify all characteristics, including the type and extent of myocardial infarction, potential damage to the left ventricle and status of coronary arteries assessed by angiography. However, we 
do not believe that important characteristics or treatments are likely to have differed between our two populations because they comprised all patients fulfilling our age criteria who were admitted to the single CCU with a stable staff and serving an entire district; the probability that, in this relatively short period (1991-1993), management of patients changed was low. Approximate estimate of myocardial damage could be assessed by the number of myocardial infarctions, which were similar in both groups. In addition, all CP and IP patients were admitted during a time when direct coronary interventions were unavailable, the rate of thrombolyses was similar, and the use of protective cardiovascular drugs (with the exception of hypolipidemics) was similar during follow-up.

A strength of our study is that no exclusion criteria with the exception of age were applied. The results should therefore be applicable to younger patients surviving myocardial infarction. In addition, as shown in the recently presented EUROASPIRE III project, no change in prevalence of smoking and continuing adverse trends in prevalence of central obesity were observed.(2) These surveys clearly show that coronary intervention and drug therapies are simply not sufficient and need to be combined with a professional lifestyle and risk factor intervention. In conclusion, multifactor intervention after myocardial infarction dramatically reduced all-cause mortality for about 2.6 years in men with a high prevalence of the metabolic syndrome and diabetes in a population with limited availability of revascularization procedures.

Thanks: We thank Pavel Podrapsky, MD, Chief of the Coronary Care Unit and Miroslav Jiranek, Director of Litomerice District Hospital, for their unfailing support and encouragement and Merck Research Laboratories for providing simvastatin for the active intervention phase of this study.

\section{Reference}

1. Widimsky P, Zelizko M, Jansky P, Tousek F, Holm F, Aschermann M. CZECH investigators. The incidence, treatment strategies and outcomes of acute coronary syndromes in the "reperfusion network" of different hospital types in the Czech Republic: results of the Czech evaluation of acute coronary syndromes in hospitalized patients (CZECH) registry. Int J Cardiol 2007;119: 212-9.

2. Kindermann M, Adam O, Werner N, Böhm M. Clinical Trial Updates and Hotline Sessions presented at the European Society of Cardiology Congress 2007: (FINESSE, CARESS, OASIS 5, PRAGUE-8, OPTIMIST, GRACE, STEEPLE, SCAAR, STRATEGY, DANAMI-2, EXTRACT-TIMI-25, ISAR-REACT 2, ACUITY, ALOFT, 3CPO, PROSPECT, EVEREST, COACH, BENEFIT, MERLIN-TIMI 36, SEARCH-MI, ADVANCE, WENBIT, EUROASPIRE I-III, ARISE, getABI, RIO). Clin Res Cardiol 2007;96:767-86.
3. Gaede P, Vedel P, Larsen N, Jensen GV, Parving HH, Pedersen O. Multifactorial intervention and cardiovascular disease in patients with type 2 diabetes. N Engl J Med 203;348:383-93.

4. Sdringola S, Nakagawa K, Nakagawa Y, et al. Combined intense lifestyle and pharmacologic lipid treatment further reduce coronary events and myocardial perfusion abnormalities compared with usual-care cholesterol-lowering drugs in coronary artery disease. J Am Coll Cardiol 2003;41:263-72.

5. Uemura K, Pisa Z. Trends in cardiovascular disease mortality in industrialized countries since 1950. World Health Stat Q 1988;41:155-78.

6. Skodova Z, Pisa Z, Vojtisek $P$, et al. Changes in the cardiovascular risk profile of the population of the Czech Republic-MONICA 1992. Cas Lek Ces 1994;133:624-6.

7. EUROASPIRE. A European Society of Cardiology survey of secondary prevention of coronary heart disease: principal results. EUROASPIRE Study Group European Action on Secondary Prevention through Intervention to Reduce Events. Eur Heart J 1997;18:1569-82. Erratum in (1998) Eur Heart J 1998;19;356-7.

8. EUROASPIRE II Study Group. Lifestyle and risk factor management and use of drug therapies in coronary patients from 15 countries; principal results from EUROASPIRE II Euro Heart Survey Programme. Eur Heart J 2001;22:554-72.

9. Multinational monitoring of trends and determinants in cardiovascular disease - MONICA Project Manual of operations 1983; WHO/MNC:82.2.

10. Peters JR, Quiter ES, Brekke ML, et al. The Eating Pattern Assessment Tool: A simple instrument for assessing dietary fat and cholesterol intake. J Am Dietetic Assoc 1994;94:1008-13.

11. Havel RJ, Rapaport E. Management of primary hyperlipidemia. N Engl J Med 1995;332:1491-8.

12. National Cholesterol Education Program (NCEP) Expert Panel on Detection, Evaluation, and Treatment of High Blood Cholesterol in Adults (Adult Treatment Panel III). Third Report of the National Cholesterol Education Program (NCEP) Expert Panel on Detection, Evaluation, and Treatment of High Blood Cholesterol in Adults (Adult Treatment Panel III) final report. Circulation 2002;106:3143-221.

13. Gray RJ. Spline-based tests in survival analysis. Biometrics 1994;50:640-52.

14. Gray RJ. Flexible methods for analyzing survival data using splines, with application to breast cancer prognosis. J Am Statistical Assoc 1994;87:942-51.

15. Cox DR. Regression models and life-tables (with discussion). J Royal Statistical Society. Series B. Methodological 1972;34:187-220.

16. Bruthans J. Report on Development of Cardiovascular Diseases in the Czech Republic after 1989. Prague: Galen, 2000:180.

17. Rosolová H, Mayer $O \mathrm{Jr}$, Simon J, Sefrna F. Detection of risk of insulin resistance in the population. Cas Lek Ces 1998;137:80-3.

18. Critchley JA, Capewell S. Mortality risk reduction associated with smoking cessation in patients with coronary heart disease. JAMA 2003;290:86-97.

19. Reaven G, Tsao PS. Insulin resistance and compensatory hyperinsulinemia: the key player between cigarette smoking and cardiovascular disease? J Am Coll Cardiol 2003;41:1044-7.

20. Poledne R, Skodova Z. Changes in nutrition, cholesterol concentration, and cardiovascular disease mortality in the Czech population in the past decade. Nutrition 2000;16:785-6.

21. Goldberg RJ, Steg PG, Sadiq I, et al. Extent of, and factors associated with, delay to hospital presentation in patients with acute coronary disease (the GRACE registry). Am J Cardiol 2002;89:791-6.

22. Bouma J, Broer J, Bleeker J, van Sonderen E, Meyboom-de Jong B, DeJongste MJ. Longer pre-hospital delay in acute myocardial infarction in women because of longer doctor decision time. J Epidemiol Community Health 1999;53:459-64.

Received 23 June 2008

Revision accepted 22 October 2009 